\title{
INNOVATIVE METHOD FOR INTRODUCTION OF WRITTEN LANGUAGE: EXPERIENCE IN MEXICO
}

\author{
Yulia Solovieva, \& Luis Quintanar Rojas \\ Master Program in Neuropsychological Diagnosis and Rehabilitation, \\ Faculty of Psychology, Puebla Autonomous University (Mexico)
}

\begin{abstract}
Introduction of written language at primary school represents one of the important aspects of school learning. In Mexico, as in many other countries, common methods of teaching are repetition, memorization and reproduction of given information: letters or syllables. Our presentation shows an example of implementation of a new method for introduction of written language based on activity theory and concept of guided orientation and comparison of the results with traditional methods. Written language is analyzed as symbolic codification and de-codification of oral words according to phonological and phonetic system of language. The Program for Training of Written language implies fulfilment of joint actions of children guided by teacher. Collective dialogue is the main type of interaction and children are free to move from place to place in the classroom. Children learn how to codify and represent oral words of Spanish language with the help of external materialized and perceptive schemes. The results of application of the method show correct pronunciation of all known and unknown words, usage of correct space between words in writing, reduced number of orthographic mistakes. After working with the method for one year children commit less mistakes in reading and writing in comparison with the pupils who learn according to traditional methods. Our proposal is a new alternative method for initial education and especially for introduction of reading and writing in primary school. The main challenges of activity theory are preparation of specific orientation within conception of the zone of proximate development.
\end{abstract}

Keywords: Innovative education, methods of teaching, written language, primary education, orientation in teaching.

\section{Introduction}

The process of teaching of reading and writing at primary school represents one of the most important aspects of child's life during this period. Learning to read and write is the point of attraction for psychologists and teachers. However, there are no real intents for searching of new ways of psychological understanding of the child's actions during introduction of reading and writing at school. In Mexico, as in many other countries, the process of reading and writing at school traditionally is based on isolated training of this cognitive ability. Common methods of teaching of reading and writing are repetition, memorization and reproduction of given information: letters or syllables. In public schools in Mexico, children never read entire books. Only pages or paragraphs of reduced and simple texts appear in official programs for primary school. Even in private schools reading acquisition is a mechanic process, which starts from the first grade of pre-school age and continues up to the sixth grade of primary school (Quintanar, \& Cols., 2011). Cognitive tests measure the quantity of words, which the child can read loudly in a minute. Understanding of the meaning and sense of texts is never taken into account. Situation with reading and understanding at all education levels in Latin America is a serious problem. Such countries as Mexico and Colombia normally occupy last places within OGDA tests. Alternative methods within active school and global reading can't solve this problem. These methods never take into account orientation, analysis of content of actions and reflexive participation of the children in their own school actions (SEP, 2010). Alternative methods are always based on the theory of constructivism or conceptions of competences.

Activity theory is a new option for proposal of new alternative methods for initial education and especially for introduction of reading and writing in primary school. The main challenges of activity theory are preparation of specific orientation for each part of knowledge. Our presentation shows an 
example of usage of orientation for initial introduction of reading and writing process in primary school. The method of orientation is based on previous methodological conceptions of Elkonin $(1980,1995)$, Galperin $(1979,1992)$, Talizina $(1988,2009)$ as main representatives of activity theory and cultural psychology. Reading and writing process is understood as a reflective and voluntary process of symbolic codification and de-codification of oral words by a subject (Luria, 1980).

\section{Method}

The authors of the method present detailed analysis of phonological and phonetic system of Spanish language as the base for introduction of symbolic codification and graphic representation of kinds of sounds of Spanish language. The Program for Training of Written language implies fulfilment of joint actions of children guided by teacher (Solovieva \& Quintanar, 2016). On each stage of the work with the method, the teacher shows children what and how should they do. The work in classroom is always collective and interactive process with no kind of individual tasks. The teacher helps children always in cases of difficulties. Children are encouraged to ask and answer questions collectively, to help each other to correct mistakes or to put examples of words and sounds. All kinds of initiative and interest of children are taken into account by teacher (Oboukhova, 2006). All tasks are shared in the group and are fulfilled collectively together with the teacher (Solovieva \& Cols., 2017). The teacher takes part as another mate of the children and as a guided of intellectual activity. Collective dialogue is the main type of interaction and children are free to move from place to place in the classroom. All procedures of the method are based on the concept of the zone of proximate development introduced by Vigotsky (1996). Children learn how to codify and represent oral words of Spanish language with the help of external materialized schemes. Collective dialogue and joint creative tasks are the main type of interaction and children are free to move from place to place in the classroom. On perceptive stage, children draw these schemes in notebooks together with examples of drawings corresponding to the words they choose. The method includes introduction of actions of codification at materialized, perceptual and verbal levels (Solovieva, 2014). Gradually, children pass to the level of reading and writing of words and sentences in Spanish. Different creative tasks and work in groups are used during the work with the method. Children use reflective orientation of all kinds of types of correspondence between the sounds and letters in Spanish language.

Stages of the Innovative Method for introduction of reading and writing:

1. Oral phonetic analysis of sounds in words. On this stage children say loudly different words they like. The teacher helps children to identify orally the sounds in each pronounced word.

2. Phonetic analysis with the help of external materialized action. On this stage, the teacher shows the scheme for words, in which the quantity of squares correspondents to quantity of sounds in the word. Children choses correspondent scheme according to the quantity of sounds and fill the schemes with the circles in correspondent places.

3. Introduction of general phonological differentiation of vowels and consonants. The vowels are symbolized as red circles, while the consonant sounds as green circles in external schemes.

4. Introduction of letters with the help of materialized external action:

- Introduction of letters which correspond to vowel sounds;

- Introduction of letters which correspond to consonant sounds (according to the order of rules for correlation between setter and sound of Spanish language);

5. Introduction of the action of writing and reading of letters:

- Writing and reading of letters which determine vowels of Spanish language;

- Writing and reading of letters which determine consonants of Spanish language;

6. Independent reading and writing of words and sentences.

\section{Results}

Our program has been applied in private primary school "Kepler" in the city of Puebla (Mexico) for six years (Solovieva \& Quintanar, 2016). The results of application of the method show correct pronunciation of all known and unknown words, usage of correct space between words in writing, reduced number of orthographic mistakes. The teachers who work now using our Method expressed notable differences between possibilities of this group and other children who were learning by traditional (analytic or global) training of reading. The children showed no difficulties in final psychological assessment. They were able to pass naturally to reading of complex narrative and artistic texts at the end of the first year of primary school. High cognitive motivation permitted introduction of profound analysis of meaning and sense of stories and short novel for children with good understanding. Children were eager to read books independently, which rarely happen in traditional Mexican schools. 


\section{Discussion}

Among strong advantages of the method is correct pronunciation of all known and unknown words in Spanish, usage of correct space between words in writing, reduced number of orthographic mistakes. The method guarantees better understanding of all regularities and exceptions of correspondence between phonological level of words and its representation with graphic symbols (letters). After working with the method for one year children commit less mistakes in reading and writing in comparison with the pupils who learn according to traditional methods (Solovieva, Torrado \& Quintanar, 2018). Another important achievement of the method is the platform for gradual introduction of theoretical thinking instead of empirical thinking predominant in pre-school age (Talizina, 1988, 2009; Davidov, 1988). We are sure that the main starting point of our Method is usage of specific orientation for oral and written analysis of words. Such orientation, introduced from external level by joint collective actions between teacher and children, permitted correct fulfillment of intellectual verbal actions of analysis and production of words and sentences. We would like to stress that the introduction of new methods elaborated according to theoretical and methodological proposals of cultural-historic psychology and activity theory could be very useful and productive. Specific orientations might be created for correction in cases of learning disabilities and prevent mistakes of confusion, inversion, omission, wrong separation and anticipation in reading and writing. Intellectual reflexive analysis of words and separation of level of sounds and letter might be used as the basis for but also as a method for acquisition of foreign language (Solovieva, 2015), which is especially important in modern global world of communication.

\section{Conclusion}

The authors are convinced that high interest and constant motivation for learning depend on orientation of each action of a pupil introduced by guidance of the teacher. Such kind of pedagogical proposal is completely based on the principles of activity theory applied to teaching process. Our proposal might be a new alternative method for initial education and especially for introduction of reading and writing in primary school. The main challenges of activity theory are preparation of specific orientation within conception of the zone of proximate development.

\section{References}

Davidov, V. V. (1988). La enseñanza escolar y el desarrollo psíquico. Moscú: Progreso.

Elkonin, D.B. (1980). Psicología del Juego. Madrid. Pablo del Rio.

Elkonin, D.B. (1995). Desarrollo psicológico en las edades infantiles. Moscú: Academia de Ciencias Pedagógicas y Sociales.

Galperin, P. Ya. (1979). Introducción a la psicología. Un enfoque dialéctico. Madrid: Pablo del Río.

Galperin, P. (1992). Stage-by-stage formation as a method of psychological investigation. Journal of Russian and East European Psychology, 30, (4), 60-80.

Luria, A. R. (1980). Fundamentos de neurolingüística. Barcelona: Toray-Mass.

Obukhova, L.F. (2006). Psicología del desarrollo. Moscú: Educación superior.

Quintanar, L., Solovieva, Yu., Lázaro, E., Bonilla, R., Mejía, L. \& Eslava, J. (2011). Dificultades en el proceso lectoescritor. México: Trillas.

SEP (2010). Manual de procedimientos para el fomento y la valoración de la competencia lectora en el aula. México: SEP.

Solovieva, Yu. (2014). Desarrollo de la actividad intelectual desde paradigma histórico-cultural. México: CEIDE.

Solovieva, Yu. (2015). Estrategias introductorias de la lectoescritura en el idioma inglés. México: Plaza y Valdés.

Solovieva, Y., \& Quintanar, L. (2016). Enseñanza de la lectura. Un método práctico. México: Trillas.

Solovieva, Yu., Baltazar Ramos, A.M., Escotto, A. \& Quintanar, L. (2017). Training of Teachers: Difficulties and Proposals in Mexico. Journal of Studies in Education. 7 (4): 78-91.

Solovieva, Yu., Torrado, O. \& Quintanar, L. (2018). Orientation for Initial Introduction of Written Speeach in primary School. Journal of Education, Society and Behavioural Science. 24 (4): 1-18.

Talizina, N. F. (1988). Psychology of teaching. Moscow: Progress.

Talizina, N. F. (2009). La teoría de la actividad aplicada a la enseñanza. México: BUAP.

Vigotsky, L. S. (1995). Obras escogidas Tomo IV. Madrid: Visor. 